\title{
COVID-19 Provides a Rare Opportunity to Create a Stronger, More Equitable Society
}

\author{
Shai Davidai ${ }^{1}$, Martin V. Day ${ }^{2}$, Daniela Goya-Tocchetto ${ }^{3}$, Oliver P. Hauser ${ }^{*}, 4$, \\ Jon M. Jachimowicz ${ }^{*}, 5$ M. Usman Mirza ${ }^{6}$, Nailya Ordabayeva ${ }^{7}$, L. Taylor Phillips ${ }^{8}$, \\ Barnabas Szaszi ${ }^{9}, \&$ Stephanie J. Tepper ${ }^{10}$ \\ ${ }^{1}$ Columbia University; ${ }^{2}$ Memorial University of Newfoundland; ${ }^{3}$ Duke University; \\ ${ }^{4}$ University of Exeter; ${ }^{5}$ Harvard University; ${ }^{6}$ Maastricht University; ${ }^{7}$ Boston College; \\ ${ }^{8}$ New York University; ${ }^{9}$ Eotvos Loránd University; ${ }^{10}$ Cornell University \\ *To whom correspondence should be addressed: o.hauser@exeter.ac.uk; jjachimowicz@hbs.edu
}

\begin{abstract}
COVID-19 - and the ensuing economic fallout — exposed society's vast inequalities. Current stimulus plans and ongoing debates revolve around restoring society to its pre-COVID-19 state, a singular focus driven by a prevalent status quo bias. We propose that policymakers should adopt a more ambitious goal: to take advantage of the change momentum of COVID-19 to reduce social inequalities in order to build society's resilience for the next time disaster strikes. We suggest that this redesign will require a focus on the multidimensional nature of social and economic inequalities, and a shift toward strengthening communities rather than a sole focus on individual households and businesses. This crisis should be seen as a unique window for restructuring society by creating new norms and ideals rather than returning to the pre-COVID19 status quo.
\end{abstract}

Keywords: COVID-19, inequality, policy, status quo bias 
Income inequality in the U.S. was at historic levels even before the COVID-19 crisis hit, but this crisis is likely to create even deeper fissures between the poor and rich. Low-income workers are more likely to have experienced income reductions and job loss, in part because they are less likely to be able to work from home; and more likely to have been designated as "essential" workers who, by the nature of their work, are at higher risk of being exposed to the virus (1-4). In addition to these risks concerning their physical and economic well-being, lowincome workers are less likely to have access to good healthcare and thus less likely to be tested and treated for COVID-19 $(5,6)$. Indeed, the widening gap between the rich and poor is likely to occur on a global scale, both within countries (7-11) as well as between poorer and richer countries (12).

Within this bleak picture, there is both encouraging and discouraging news. As social scientists studying the antecedents and consequences of societal inequalities, we are heartened to see swift policy actions taken in countries around the globe to direct cash payments to lowincome individuals, for example through stimulus checks in the U.S., government-assisted furlough payments in the U.K., or universal basic income in Spain. We are also encouraged by the recognition among participants in a recent U.S. survey that COVID-19 has increased income inequality, and widespread agreement that governments should commit to reducing it (13).

At the same time, we are worried that the prevailing attitude falls prey to the "status quo bias" (14), with politicians, policymakers, and lay people wishing to restore "the way things were before the COVID-19 crisis." Indeed, because societies around the world are currently operating under conditions of uncertainty and economic scarcity, most of us are more likely to focus on immediate and short-term solutions (15) and favor the reduction of present (and future) losses (16) rather than the creation of new potential gains. 
But this moment in time is also an opportunity to take a closer look at society and realize that the conditions of a pre-COVID-19 world were strongly responsible for making this virus (and the ensuing economic fallout) particularly disastrous. Paraphrasing the late sociologist Charles Perrow (17), there are no such things as "natural disasters." Indeed, there is nothing natural about disasters because their impact is the result of the way society is structured. Viewed from this lens, the goal of policy-makers during the COVID-19 pandemic should not be to reactively restore the status quo. Instead, the goal should be to proactively restructure society so we are all more resilient the next time disaster strikes.

Achieving this goal of resilience requires a clear understanding of what aspects of society need strengthening. While it is critical for policymakers to consider disparities of income, they also need to expand their focus. The COVID-19 crisis highlights the deeply entrenched connections between multiple dimensions of inequalities in society, i.e., the multifaceted and complex nature of inequality (18). Who can afford to risk an infection? Who gets to wear masks in public without a second thought about racial profiling? Who takes on childcare responsibilities when parents can work from home? ${ }^{1}$ These inequalities have always been present in our society, but COVID-19 is unique in that it highlights them all simultaneously.

Because inequality is multi-faceted, policy debates must be as well. Whereas politicians have been focusing on how to distribute an "economic stimulus" plan, such as between business owners and individuals, this debate is insufficient because it focuses only on restoring prior income. Instead, a more resilient future requires an integration of the different dimensions of inequality that are intimately connected but often "invisible" under the surface (19). Gender, race, age, and socioeconomic status, among other dimensions, have always been "fault lines"

\footnotetext{
${ }^{1}$ A trend that can be seen in our own field, with journal submissions - the currency of academic success - revealing greater gender rifts since the onset of the pandemic (36).
} 
along which inequality splits, but COVID-19 is helping us see those lines more clearly, revealed all at once. Now that these fault lines have been exposed, politicians on either side of the aisle can no longer pretend they are not there, or deal with only one seam at a time. Seaming one fault line while keeping the others unchecked will leave society exposed to the same threats it is currently experiencing. To strengthen society as a whole we must consider the system as a whole.

Policies should be evaluated by their potential to simultaneously address multiple dimensions of inequality and create a level playing field for future economic mobility (20-22). Income is obviously a dimension that should not be missed: Policy-makers should ensure that the gains that a rebooted economy will inevitably deliver are redistributed more equally, not simply accumulated among the top $1 \%$. But we should also push to go beyond just income. We could, for example, use the lockdown to change the norms around childcare, such as incentivizing women and men equally to stay home even after the COVID-19 lockdowns have ended, or by providing free child care support and early childhood education. We could ensure more equitable access to healthcare and childcare, regardless of employment status, income, or race, and expand sick leave protections. We could ensure more equitable access to broadband connections which have become so crucial in a time where online services are rapidly transforming our educational, financial, and health systems. These are not partisan appeals, but proposals grounded on solid scientific evidence, accumulated over decades of social science research (23-25).

Finally, as social scientists, we understand the crucial role played by the social fabric in which people are embedded, a role that becomes especially critical in times of hardship and difficulty. New policy proposals that are needed now could consider the role of local communities, which play a key role in creating the psychological and economic well-being that 
ameliorates the effect of inequalities (26-28). To boost stronger community ties, policy-makers could, for example, provide incentives to households in the form of vouchers or rebates to redeem stimulus assistance at local businesses, which would also help boost the economy locally. Similarly, policy-makers might provide local grants to empower those organized in the community, reflecting their on-the-ground knowledge of community fault lines and ability to find apposite solutions $(29,30)$. While such interventions may not reduce inequality alone, they may reduce the negative effects of inequality by strengthening community ties.

We are in a pivotal moment in modern history which has documented parallels with the Great Depression. Now, as then, we are living through a moment of crisis that also affords us an opportunity to reshape the inequalities we have come to take for granted. Whereas the policies dealing with the Great Depression helped reduce income inequality in the U.S. ${ }^{2}$ and Europe, today's COVID-19 policies need to go a step further, recognizing the existence — and the interconnectedness - of various types of inequalities. History suggests that the impact of pandemics on the socioeconomic order depends on policy choices and the will of policy-makers $(31,32)$. Rebuilding will require a policy agenda focused on the long-term that fairly distributes resources across individuals, groups, and generations (33). This is as much a pragmatic issue as it is a moral one. Let us use this fresh start to set new policy and social norms $(34,35)$ that have the power to sustainably reduce inequality in the future.

\footnotetext{
2 The Social Security program, which supports financially secure life for elderly men and women throughout the United States was enacted as a direct reaction to the Great Depression of the 1920s and 1930s.
} 


\section{References}

1. A. Adams-Prassl, T. Boneva, M. Golin, C. Rauh, Inequality in the Impact of the Coronavirus Shock: Evidence from Real Time Surveys. Cambridge-INET Work. Pap. Ser. No 2020/18 (2020).

2. T. Hanspal, A. Weber, J. Wohlfart, Income and Wealth Shocks and Expectations during the COVID-19 Pandemic. SSRN (2020) (available at https://papers.ssrn.com/sol3/papers.cfm?abstract_id=3577217).

3. L. Hensvik, T. Le Barbanchon, R. Rathelot, Which jobs are done from home? Evidence from the American Time Use Survey. SSRN (2020) (available at https://doi.org/10.2139/ssrn.3574551).

4. C. Robertson, R. Gebeloff, How Millions of Women Became the Most Essential Workers in America. New York Times (2020), (available at https:/www.nytimes.com/2020/04/18/us/coronavirus-women-essentialworkers.html?referringSource $=$ articleShare).

5. B. Poston, T. Barboza, A. Jennings, California coronavirus cases: Tracking the outbreak. LA Times (2020).

6. S. Schmitt-Grohé, K. Teoh, M. Uribe, Covid-19: Testing Inequality in New York City. NBER Work. Pap. (2020) (available at https://doi.org/10.3386/w27019).

7. R. Baldwin, The COVID-19 upheaval scenario: Inequality and pandemic make an explosive mix. VoxEU (2020).

8. M. Lucchese, M. Pianta, The Coming Coronavirus Crisis: What Can We Learn? Intereconomics. 55, 98-104 (2020).

9. W. J. McKibbin, R. Fernando, "The global macroeconomic impacts of COVID-19: Seven scenarios." (2020).

10. K. Parker, J. M. Horowitz, A. Brown, About Half of Lower-Income Americans Report Household Job or Wage Loss Due to COVID-19. Pew Res. (2020).

11. \& Y. E. Caria, S., Fetzer, T., Fiorin, S., Götz, F. M., Gomez, M., Haushofer, J., Hensel, L., Ivchenko, A., Jachimowicz, J., Kraft-Todd, G., Reutskaja, E., Roth, C., Witte, M., "Measuring worldwide COVID-19 attitudes and beliefs" (2020).

12. C. Hevia, P. A. Neimeyer, A perfect storm: COVID-19 in emerging economies. VoxEu (2020).

13. A. White, Harris Poll: Most Americans Want Government Intervention To Reduce Inequality. ScienceBlog (2020), (available at https://scienceblog.com/515583/harris-pollmost-americans-want-government-intervention-to-reduce-inequality/).

14. W. Samuelson, R. Zeckhauser, Status quo bias in decision making. J. Risk Uncertain. 1, 7-59 (1988).

15. A. K. Shah, S. Mullainathan, E. Shafir, Some consequences of having too little. Science. 338, 682-5 (2012).

16. A. Tversky, D. Kahneman, Loss Aversion in Riskless Choice: A Reference-Dependent Model. Q. J. Econ. 106, 1039-1061 (1991).

17. C. Perrow, The Next Catastrophe (Princeton University Press, 2011).

18. O. P. Hauser, C. Hilbe, K. Chatterjee, M. A. Nowak, Social dilemmas among unequals. Nature. 572, 524-527 (2019).

19. L. T. Phillips, B. S. Lowery, Herd Invisibility: The Psychology of Racial Privilege. Curr. Dir. Psychol. Sci. 27, 156-162 (2018). 
20. S. Davidai, Why do Americans believe in economic mobility? Economic inequality, external attributions of wealth and poverty, and the belief in economic mobility. J. Exp. Soc. Psychol. 79, 138-148 (2018).

21. S. Davidai, T. Gilovich, Building a More Mobile America-One Income Quintile at a Time. Perspect. Psychol. Sci. 10, 60-71 (2015).

22. M. V. Day, S. T. Fiske, in The Social Psychology of Inequality (Springer, 2019), pp. 365380 .

23. I. Bohnet, What Works: Gender Equality by Design (Harvard University Press, 2016).

24. D. Choe, R. Seamans, "Broadband Availability Affects Working from Home" (2020).

25. C. Jordan, Inequities in COVID-19 are tragic but preventable. Hill (2020).

26. R. Chetty, N. Hendren, P. Kline, E. Saez, Where is the land of opportunity? The geography of intergenerational mobility in the United States. Q. J. Econ. 129, 1553-1623 (2014).

27. J. M. Jachimowicz, S. Chafik, S. Munrat, J. C. Prabhu, E. U. Weber, Community trust reduces myopic decisions of low-income individuals. Proc. Natl. Acad. Sci. 114, 54015406 (2017).

28. J. Jachimowicz, B. Szasi, M. Lukas, D. Smerdon, J. Prabhu, E. Weber, Higher Economic Inequality Intensifies the Financial Hardship of People Living in Poverty by Fraying the Community Buffer. Nat. Hum. Behav. in press (2020).

29. J. Haushofer, J. Shapiro, The short-term impact of unconditional cash transfers to the poor: Experimental evidence from kenya. Q. J. Econ. 131, 1973-2042 (2016).

30. A. Smith, M. Fressoli, H. Thomas, Grassroots innovation movements: Challenges and contributions. J. Clean. Prod. 63, 114-124 (2014).

31. W. Scheidel, The Great Leveler: Violence and the History of Inequality from the Stone Age to the Twenty-First Century (Princeton University Press, 2018).

32. W. Scheidel, Why the Wealthy Fear Pandemics. New York Times (2020).

33. O. P. Hauser, D. G. Rand, A. Peysakhovich, M. A. Nowak, Cooperating with the future. Nature. 511, 220-223 (2014).

34. R. B. Cialdini, C. A. Kallgren, R. R. Reno, A Focus Theory of Normative Conduct: A Theoretical Refinement and Reevaluation of the Role of Norms in Human Behavior. Adv. Exp. Soc. Psychol. 24, 201-234 (1991).

35. M. E. Tankard, E. L. Paluck, Norm Perception as a Vehicle for Social Change. Soc. Issues Policy Rev. 10, 181-211 (2016).

36. O. Shurchkov, Is COVID-19 turning back the clock on gender equality in academia? Medium (2020). 